\title{
LIFELONG LEARNING JAKO WYZWANIE DLA SAMORZĄDU TERYTORIALNEGO
}

\section{LIFELONG LEARNING AS A CHALLENGE FOR LOCAL GOVERNMENTS}

\section{Streszczenie}

Lifelong learning, jako idea edukacji całożyciowej, to kluczowa kategoria współczesnego świata, świata dążącego do stworzenia społeczeństwa opartego na wiedzy. Edukacja, a wraz z nią jednostki samorządu terytorialnego oraz podlegające im instytucje stoją przed nowymi wyzwaniami związanymi z koniecznością wdrażania każdego człowieka w proces uczenia się przez całe życie w trzech wymiarach: formalnym, nieformalnym i okazjonalnym. Realizacja idei społeczeństwa opartego na wiedzy oznacza więc dla organów samorządowych konieczność nie tylko koordynowania pracy instytucji oświatowych, ale nade wszystko kreowania przestrzeni dla rozwoju szeroko rozumianej edukacji i wymiany doświadczeń międzypokoleniowych. Także dążenia agend edukacyjnych państw UE zmierzają do tworzenia takich warunków, aby każdy człowiek miał szansę na pełne zbudowanie swojego habitusu społecznego.

Myślą przewodnią naszego opracowania będą słowa „uczyć się aby być”, zaczerpnięte z Raportu Jaquesa Delorsa, (jednego z najważniejszych propagatorów edukacji całożyciowej) przygotowanego dla UNESCO.

Słowa kluczowe: lifelong learning; edukacja; społeczeństwo oparte na wiedzy; samorząd lokalny. 


\begin{abstract}
Lifelong learning, as the idea of lifelong education is the key category of the modern world, a world seeking to create a knowledge-based society. Education, and with it the local government units and subordinate institutions are facing, facing new challenges with the need of implementation of every human being in the process of learning throughout life in three dimensions: formal, informal and occasional. The idea of a knowledge society, then, is for the local government bodies need to not only coordinate the work of educational institutions, but above all, creating space for the development of broadly understood education and exchange of experience between generations. Also educational aspirations agencies of EU countries aim to create conditions so that every person has the chance to complete the construction of its social habitus.

The keynote of our article are words "learn to be" taken with Jaques Delors Report, (one of the most important proponents of lifelong education ) prepared for UNESCO.
\end{abstract}

Keywords: lifelong learning, education, knowledge-based society, local government.

\title{
1. Wstęp
}

Idea lifelong learningu, idea edukacji całożyciowej, zyskuje na znaczeniu pojawiając się zarówno w rozważaniach teoretycznych, jak i w opartych o nie rozwiązaniach praktycznych w obszarze polityki społecznej i samej edukacji. Dzieje się tak przede wszystkim na skutek szybkich przemian cywilizacyjnych, w konsekwencji których wiedza i umiejętności nabyte w toku formalnej edukacji szybko się dezaktualizują lub/i pozostają niewystarczające dla realizacji zadań zawodowych i życiowych jednostki. Taki stan rzeczy powoduje, że ludzie muszą nauczyć się uczyć, podejmować trud samoedukacji, samorealizacji, aby w pełni uczestniczyć w życiu politycznym, gospodarczym, czy kulturowym kraju. W efekcie tych samych zmian dominującym staje się model społeczny, w którym kluczową rolę odgrywa wiedza - nauka i kapitał intelektualny, czyli społeczeństwo oparte na wiedzy, a miejsce celu kształcenia, jakim niegdyś było wyposażenie jednostki w zamknięty system informacji i sposobów działania, zajmuje wyposażenie jej w umiejętność uczenia się i operowania nabywaną wiedzą, która ma służyć przez całe życie. Dyspozycje konieczne do uczenia się przez całe życie: dziecięca ciekawość, aktywność i samodzielność, zaczynają więc być akcentowane i rozpoznawane jako wartościowe na 
gruncie pedagogiki przedszkolnej (co znajduje swe odzwierciedlenie w podstawie programowej wychowania przedszkolnego ${ }^{1}$ ), z nadzieją na ich rozwijanie i wykorzystywanie przez całe życie jednostki.

Tym samym edukacja, a wraz z nią organizujące ją jednostki samorządu terytorialnego oraz podlegające im instytucje, stoją przed nowymi wyzwaniami związanymi z koniecznością wdrażania każdego człowieka w proces całożyciowego uczenia się oraz organizowania sprzyjających temu procesowi warunków. Ponieważ lifelong learning dokonuje się nie tylko w ramach edukacji formalnej, lecz także poza nimi - w edukacji nieformalnej - ucieleśnianie jego idei angażuje szeroki i ,różnorodny obszar instytucji, stowarzyszeń, bodźców i impulsów informacyjnych oraz sytuacji edukacyjnych ogarniających dzieci i młodzież (a także dorosłych) w środowisku pozaszkolnym. (...) Dotyczy to (...) wszelkiego rodzaju uczenia się okazjonalnego, incydentalnego poprzez uczestnictwo w zabawie, pracy, w kontaktach z rówieśnikami, w spędzaniu czasu wolnego."2 Bogactwo i struktura owych bodźców istotnie zależą od organizacji środowiska lokalnego.

Dążenie do realizacji idei społeczeństwa opartego na wiedzy oznacza więc dla organów samorządowych konieczność nie tylko koordynowania prac instytucji oświatowych, ale nade wszystko kreowania przestrzeni dla rozwoju szeroko rozumianej edukacji i wymiany doświadczeń międzypokoleniowych. Tendencji do wydłużania się okresu edukacji, dzięki któremu Polska staje się krajem ludzi uczących się, towarzyszy konieczność budowania długofalowych strategii rozwoju sektora edukacyjnego w jednostkach samorządu terytorialnego, dla których finansowanie zadań oświatowych jest jedną z głównych pozycji w budżetach ${ }^{3}$. Środowisko lokalne, a w nim zadania realizowane przez jednostki samorządu terytorialnego, stanowią więc istotny kontekst całożyciowego uczenia się, który wpływa na jego jakość, intensywność i efektywność.

1 Por.: Rozporządzenie Ministra Edukacji Narodowej z dnia 30 maja 2014 r. zmieniające rozporządzenie w sprawie podstawy programowej wychowania przedszkolnego oraz kształcenia ogólnego w poszczególnych typach szkół (Dz.U., poz. 803).

2 E. Trempała, Edukacja formalna (szkolna) i edukacja nieformalna (równoległa, nieszkolna, pozaszkolna), „Przegląd Pedagogiczny” 2011, nr 1, s. 98.

3 M. Kędzierski, Jednostki samorzqdu terytorialnego wobec wyzwań edukacyjnych, http://witrynawiejska.org.pl/data/M Kedzierski - Edukacja w samorzadzie.pdf (dostęp: 26.06.2016 r.). 


\title{
2. Od edukacji dorosłych do edukacji całożyciowej - wprowadzenie w problematykę
}

\author{
Człowieka nuży wszystko z wyjątkiem nauki
}

Wergiliusz (70-19 p.n.e.)

Pojęcie lifelong learningu kształtowało się powoli. Ewoluowała także jego treść: od edukacji dorosłych poprzez edukację ustawiczną aż po edukację całożyciową rozumianą nie jako wycinek rzeczywistości edukacyjnej, ale jako proces ciągły.

Już XVII-wieczny pedagog Jan Amos Komeński w „Wielkiej dydaktyce” pisał, że: „nie wolno procesu kształtowania człowieka zamykać po osiągnięciu pełnej dojrzałości, lecz należy kontynuować go przez całe jego życie, umiejętnie podsycając ludzkie aspiracje samokształceniowe i perfekcjonistyczne, to bowiem odróżnia człowieka od świata zwierząt, że nie poprzestaje na już osiągniętym etapie poznania i doskonałości, lecz dąży nieustannie do przekroczenia granic samego siebie i osiągnięcia nowego, wyższego szczebla rozwoju"4.

Jego zdaniem edukacja nie jest przywilejem tylko i wyłącznie dzieci i młodzieży, w procesie tym mogą i powinni brać udział także dorośli. Potrzebę uczenia się ludzi dorosłych dostrzegał także Nikolai S.F. Grundtvig, który jest twórcą uniwersytetów ludowych. Idąc krok dalej zwracał uwagę nie tylko na konieczność udziału dorosłych w edukacji, ale też na kształtowanie w tej grupie aspiracji poznawczych, poczucia własnej wartości i korzystania ze wszystkich szans społecznych dla dobra narodu.

Zdaniem Floriana Znanieckiego mylne jest myślenie, że dorośli nie wymagają wychowania, ponieważ dają sobie radę w życiu. Dorośli dużo gorzej radzą sobie w swojej sferze działania niż dzieci ${ }^{5}$, dlatego też za sprawą wychowania należy doprowadzić do tego, że osoba dorosła zacznie spełniać swoje funkcje społeczne w życiu i będzie wypełniać role społeczne wyznaczone jej przez zbiorowość. Warunkiem skutecznego oddziaływania na ludzi dorosłych jest głębokie i prawdziwe ich poznanie, przede wszystkim od strony reprezentowanych przez nich układów zamkniętych, przyzwyczajeń, norm i ideałów, określających poprzez ich styl myślenia i działania ich stosunek do wielu podstawowych wartości życia społecznego ${ }^{6}$.

J.A. Komeński, cyt. za: L. Turos, Andragogika ogólna, Warszawa 1999, s. 11.

F. Znaniecki, cyt. za: L. Turos, Andragogika .., s. 38.

Tamże, s. 42. 
Powyższe rozważania pokazują, że aby mówić o pełnym rozwoju jednostek - z myślą o pełnym rozwoju społecznym, winniśmy skupić się na wszystkich grupach wiekowych, nie rozdzielać przywileju uczenia się na wybrane grupy, ale nauczyć ludzi budowania społeczeństwa opartego na wiedzy - wiedzy zdobywanej w różnych przestrzeniach. W ten sposób bowiem, nie tylko spełnimy postulaty edukacji całożyciowej, ale nade wszystko obudzimy w ludziach potrzebę ciągłego samodoskonalenia - a tylko w ten sposób zapewnimy sobie stabilne społeczeństwo, gotowe do zmian. $Z$ tego też powodu budując system edukacji winniśmy zapewnić wszystkim grupom możliwość pełnego do niej dostępu, a zatem bez wyłączania ludzi dorosłych, których w sposób aktywny należy włączyć w proces edukacji, pozyskując i wykorzystując ich potencjał. Jest to ważny obszar oddziaływań edukacyjnych, albowiem, jak podkreślał to Ignacy Solarz, ,złoża bogate w duszach noszą ludzie, trzeba je tylko uruchomić, rozszerzyć horyzonty, wzmocnić chcenie. Siłę tego chcenia, aktywność ludzką wywołać trzeba przez dostarczenie silnych osobistych przeżyć, bo z nich rodzi się żywy protest i bunt przeciw odczutemu złu, albo też mocny poryw ku dobru"7.

Edukacja ustawiczna jako koncepcja wychowawcza przełamuje tradycyjny podział życia człowieka na wiek szkolny, w którym młody człowiek zdobywa wykształcenie i kwalifikacje, i na długi wiek poszkolny, w którym człowiek w swej społecznej i profesjonalnej działalności wykorzystuje wykształcenie uzyskane w szkole. Edukacja ustawiczna odnosi się do całego życia człowieka, każdemu okresowi życia wyznaczając określone funkcje w ciągłym procesie edukacyjnym, wymagając przy tym ciągłej adaptacji do zmieniających się warunków. Jej realizacja skutkuje pojawieniem się w dyskursie społecznym i pedagogicznym następujących tendencji:

- cezura między drabiną szkolną i kształceniem poszkolnym ulega zaniżaniu lub likwidacji;

- następuje silne sprzężenie szkoły jako instytucji wychowawczej z ogólnym procesem rozwoju społeczno-ekonomicznego;

- szkoła zatraca charakter zamkniętego środowiska wychowawczego izolującego młodzież. Staje się instytucją otwartą, o różnych formach integracji ze środowiskiem pozaszkolnym, z instytucjami społecznymi i kulturowymi;

$7 \quad$ I. Solarz, cyt. za: L. Turos, Andragogika..., s. 44. 
- rozwój edukacji ustawicznej wymaga, by młody człowiek opuszczając szkołę odczuwał potrzebę dalszego kształcenia się i posiadał umiejętność zaspokojenia tej potrzeby;

- w edukacji ustawicznej preferuje się te metody nauczania, które prowadzą do rozwijania samodzielności rozumowania, umiejętności wykorzystania różnych źródeł informacji, stawiania problemów i ich rozwiązywania ${ }^{8}$.

Istotę kształcenia ustawicznego najpełniej wyraża pogląd mówiący, iż obejmuje ono całe życie człowieka i służy jego rozwojowi. Stanowi naczelną zasadę określającą kierunek współczesnych reform oświatowych dotyczących szkolnictwa powszechnego, zawodowego i wyższego, a także doskonalenia zawodowego pracujących i oświaty dorosłych, kształcenia równoległego oraz wychowania w rodzinie i środowisku. Głównym zadaniem edukacji ustawicznej jest wychowanie nowego typu człowieka, charakteryzującego się twórczym i dynamicznym stosunkiem do życia i kultury, człowieka, który potrafi doskonalić siebie, zmienić warunki życia i ulepszyć je dla dobra społeczeństwa9.

Paul Legrand przedstawiając koncepcję kształcenia ustawicznego zwrócił uwagę, że „kształcenie ustawiczne jest to cały zespół działań i zadań zmierzających do stworzenia nowego systemu edukacyjnego" ${ }^{\prime 1}$. Według niego należy zadbać o rozwój edukacji dorosłych, zwracając uwagę, że uczniów już od najmłodszych lat należy uczyć uczenia się i wyrobić w nich nawyk uczenia się przez całe życie.

Koncepcja kształcenia permanentnego zawiera w sobie odniesienia do różnych pozaedukacyjnych aspektów życia - jak chociażby ,społeczno-kulturowego, historycznego i filozoficznego usytuowania jednostek i społeczeństw w strukturach lokalnych, narodowych i globalnych". Koncepcja edukacji ustawicznej nie powinna zasklepiać się jedynie w stwierdzeniu, że odnosi się do całego życia człowieka, czy też podkreślać, że nie jest to proces ograniczający się tylko do okresu dzieciństwa i wczesnej młodości, czy też działań instytucji oświatowych. Idea kształcenia przez całe życie ma na

$8 \quad$ R. Wroczyński, Edukacja ustawiczna, [w:] W. Pomykało (red.), Encyklopedia pedagogiczna, Warszawa 1997, s. 175.

9 Z.P. Kruszewski, J. Półturzycki, E.A. Wesołowska (red.), Kształcenie ustawiczne. Idee i doświadczenia, Płock 2003, s. 8.

10 A. Matlakiewicz, Koncepcja edukacji ustawicznej w ujęciu Międzynarodowej Encyklopedii Edukacji Dorosłych i Kształcenia Zawodowego, [w:] Z.P. Kruszewski, J. Półturzycki, E.A. Wesołowska (red.), Kształcenie ustawiczne..., s. 20. 
celu wypracowanie organizacyjnych i dydaktycznych struktur i strategii, które umożliwiają podjęcie nauki od dzieciństwa po okres starości ${ }^{11}$.

Rozwój edukacji ustawicznej nadaje też nową rangę wychowaniu równoległemu. Wynika to przede wszystkim z tego, że szkoła nie daje zasobu wiedzy na całe dojrzałe życie człowieka, ale daje jedynie wyposażenie wyjściowe, które jest następnie stale poszerzane i pogłębiane. Terenem, na którym dokonuje się proces poszerzenia i rekonstrukcji wykształcenia wyjściowego, jest wychowanie równoległe, które obejmuje zarówno wpływy na świadomość i osobowość człowieka wynikające z bezpośredniego uczestnictwa w życiu społecznym i kulturalnym, jak i oddziaływanie zorganizowane w instytucjach wychowania równoległego, przeznaczonych zarówno dla młodzieży, jak i dorosłych ${ }^{12}$.

R.H. Dave wyodrębnił 25 cech charakteryzujących edukację ustawiczną. Z listy tej trzy czynniki są uznane za kluczowe dla realizacji koncepcji kształcenia ustawicznego:

- należy stworzyć obiektywne możliwości uczenia się dla wszystkich;

- odwoływać się do motywacji;

- wdrażać do „edukabilności”, to znaczy doskonalić umiejętność uczenia się, przygotować i zachęcać uczniów do samodzielnego kształcenia ${ }^{13}$.

Dostrzeżenie potrzeby zmian wynikających z wyzwań stało się jednym z powodów ogłoszenia roku 1996 Rokiem Edukacji Ustawicznej. Przyświecały temu następujące cele:

- uczynić społeczeństwo europejskie świadomym wagi całożyciowego kształcenia się jako kluczowego czynnika personalnego rozwoju jednostek $\mathrm{i}$ ich uczestnictwa w demokratycznych procesach podejmowania decyzji;

- wypracować zasady lepszej współpracy na wszystkich szczeblach pomiędzy strukturami edukacji i kształcenia zawodowego a światem biznesu;

- przyczynić się do europejskiej konkurencyjności i wzrostu gospodarczego poprzez uświadomienie partnerom społecznym, jak ważnym jest tworzenie możliwości uczenia się przez całe życie, aby odpowiedzieć na wyzwania zmiany społecznej i ekonomicznej;

- zaakcentować wagę oferowania dostępu do edukacji ustawicznej i odpowiedniego systemu akredytacyjnego dla wszystkich, bez względu na płeć, wiek, zdolności, korzenie etniczne, ekonomiczne i społeczne, z uwzględnieniem likwidowania marnotrawstwa talentów, dania dziewczętom

1 A. Matlakiewicz, Koncepcja edukacji..., s. 22.

12 R. Wroczyński, Edukacja ustawiczna..., s. 176.

13 A. Matlakiewicz, Koncepcja edukacji..., s. 21. 
i kobietom szansy wyboru z szerszego wachlarza zawodów; eliminacji różnic regionalnych;

- zachęcić rodziców i władze edukacyjne do wzięcia na swoje barki odpowiedzialności za edukację dzieci i młodych ludzi w kontekście edukacji ustawicznej ${ }^{14}$.

Realizacja edukacji ustawicznej oznacza konieczność koncentracji uwagi na jej trzech, wyodrębnionych przez Roberta Kidda wymiarach: kształceniu w pionie obejmującym kolejne szczeble edukacji szkolnej - od przedszkola poprzez szkołę do studiów wyższych i podyplomowych; zasady drożności i dostępności gwarantują młodzieży i dorosłym spełnienie się w tym wymiarze, niezależnie od wieku, zawodu, miejsca zamieszkania i innych czynników utrudniających edukację, kształceniu w poziomie, które wiąże się z zapewnianiem poznawania różnych dziedzin życia, nauki i kultury niezależnie od studiów pionowych; likwidacja sztucznych barier między dziedzinami życia i kultury umożliwia pełne wykorzystanie tego wymiaru dzięki indywidualnej aktywności człowieka i dzięki działalności pozaszkolnych instytucji oświatowych, kształceniu w głąb, które jest ściśle związane z jakością edukacji i wyraża się w bogatej motywacji kształcenia, w umiejętnościach samokształceniowych, zainteresowaniach intelektualnych, w stylu życia zgodnym z ideą ustawicznego kształcenia i kulturalnym wykorzystaniem czasu wolnego ${ }^{15}$.

Pojęcie edukacji ustawicznej bywa więc różnie interpretowane w zależności od przyjętej perspektywy. Można jednak za P.J. Suttonem wyodrębnić wspólne elementy ujmowania tej koncepcji. Należą do nich:

- pragnienie powszechnego dostępu do edukacji, obejmującej swoim zasięgiem dzieci i dorosłych, którzy aktualnie mają ograniczone możliwości kształcenia;

- uznanie wagi „usytuowania” edukacji poza instytucjami formalnymi;

- różnorodność materiałów do uczenia się;

- wspieranie i kształtowanie u uczniów cech osobowych przydatnych w procesie ciągłego uczenia się, motywacji i zdolności niezbędnych do podejmowania samokształcenia. Zawierające się w pojęciu edukacji ustawicznej uczenie się ma umożliwić każdej jednostce dalsze rozwijanie swojego fizycznego, psychicznego, emocjonalnego i intelektualnego potencjału ${ }^{16}$.

14 Tamże, s. 24.

15 J. Półturzycki, Kształcenie ustawiczne i jego konsekwencje dla edukacji, [w:] Z.P. Kruszewski, J. Półturzycki, E.A. Wesołowska (red.), Kształcenie ustawiczne ..., s. 49-50.

16 Tamże, s. 30. 
Edukacja przez całe życie, będąca ,ustawicznym kształtowaniem istoty ludzkiej, jej wiedzy i umiejętności, jej zdolności osądu i działania"17 jest więc niezbędnym elementem koncepcji społeczeństwa uczącego się, społeczeństwa przyszłości. Aby mogła być ucieleśniana w pełnym zakresie winna odbywać się zarówno w instytucjach kształcenia formalnego, jak i w przestrzeni nieformalnej i okazjonalnej, co z kolei wymaga zaangażowania różnych, współpracujących sił społecznych oraz takich regulacji formalnych, które sprzyjają realizacji jej idei.

\section{Od społeczeństwa wiedzy do społeczeństwa obywatelskiego: edukacja a rozwój}

Idei lifelong learningu oraz jej roli w i dla społeczeństw lokalnych nie sposób oderwać od takich kategorii jak społeczeństwo uczące się, społeczeństwo wiedzy, a w końcu społeczeństwo obywatelskie. O żadnym z tych modeli nie może być bowiem mowy bez ustawicznego, wielowymiarowego uczenia się wszystkich obywateli, bez gotowości do przyjmowania zmian jako naturalnego motoru rozwoju, odpowiadania na nie własnym rozwojem i generowania ich - tak w wymiarze jednostkowym, jak i społecznym. Budowa społeczeństwa obywatelskiego oznacza więc ni mniej ni więcej tylko proces uczenia się: jednostek, społeczności i społeczeństwa dla rozwoju, czyli ku wyższej jakości. Relacja edukacji z jakością życia i rozwojem społeczeństwa, zwłaszcza w wymiarze lokalnym, ma przy tym charakter dwukierunkowy - z jednej strony konieczność jej organizacji jest obciążeniem dla budżetów samorządów terytorialnych, a więc i całych społeczności, a z drugiej - jej efekty nie tylko sprzyjają rozwojowi tejże społeczności, lecz wręcz go warunkują. Informacja, a za nią wiedza, którą jednostka jest w stanie efektywnie operować nabierają wymiernej wartości. Stają się kapitałem lub warunkują istnienie kapitału - w zależności od przyjętej perspektywy - ludzkiego, intelektualnego, społecznego.

W świetle współczesnych analiz ekonomicznych wiedza, jako niewyczerpywalny, niekończący się zasób, który przyczynia się do wytwarzania innych zasobów (także materialnych) stanowi główny czynnik rozwoju. Mechanizm ten stanowi istotę gospodarki opartej na wiedzy, definiowanej przez OECD

17 T. Wujek, Kształcenie ustawiczne w świetle Raportu Jaquesa Delorsa, [w:] H. Bednarczyk (red.), Wokól problemów ksztatcenia ustawicznego, Warszawa-Ryki-Radom 1999, s. 38. 
i Bank Światowy jako ,gospodarka, w której wiedza jest tworzona, przekazywana, wykorzystywana efektywnie przez przedsiębiorstwa, organizacje, jednostki, społeczności, wspólnoty w celu zwiększania rozwoju społeczno-gospodarczego." $18 \mathrm{Z}$ tego punktu widzenia wysiłek i koszty ponoszone na rzecz organizacji edukacji wszystkich szczebli, w tym także na rzecz tworzenia warunków dla rozwoju i funkcjonowania edukacji nieformalnej stają się opłacalną inwestycją.

Jeszcze większego znaczenia edukacja całożyciowa nabiera, gdy poza korzyściami ekonomicznymi uwzględni się dalece szersze korzyści społeczne, za centralną dla oglądu problemu uznając jakże współczesną kategorię społeczeństwa wiedzy. Najistotniejszą cechą tego społeczeństwa jest uznanie wiedzy za dobro najcenniejsze, najbardziej pożądane ${ }^{19}$. Co więcej, wiedza zarówno ma wartość (w wymiarze ekonomicznym), jak również sama w sobie jest wartością (w wymiarze społecznym). Szeroko rozumiana edukacja na każdym etapie życia nabiera więc w tym modelu specjalnego znaczenia.

Społeczeństwo wiedzy nie tylko tworzy wiedzę, lecz także inwestuje w zdolność do jej ponownego wykorzystania, a decyzje są w nim podejmowane w sieciach przez ludzi, którzy nią dysponują. Na bardzo istotną jego cechę zwrócił uwagę P. F. Drucker, któremu przypisuje się autorstwo pojęcia „,społeczeństwo wiedzy”, według którego polega ono na „organizacji, w której praktycznie każde zadanie społeczne jest wypełniane przez organizację"20. Takie jego cechy jak decentracja, samoregulacyjność, otwartość, odwaga intelektualna, kreatywność, przekonanie o swoich dużych możliwościach i umiejętność ich innowacyjnego wykorzystywania ${ }^{21}$ wiążą jego istotę $\mathrm{z}$ istotą społeczeństwa obywatelskiego.

Powrót idei społeczeństwa obywatelskiego według J. Szackiego jest jednym z najciekawszych zjawisk w zakresie ewolucji zainteresowań i aparatury pojęciowej nauk społecznych ${ }^{22}$. Ożywienie zainteresowania jego koncepcją w Europie Środkowo-Wschodniej, obserwowane już wcześniej, rozwinęło się

18 I. Stalończyk, Edukacja formalna i pozaformalna w procesie ksztaltowania społeczeństwa wiedzy, „Nierówności Społeczne a Wzrost Gospodarczy” 2014, nr 1 (37), s. 322.

19 A. Lipski, Co wiemy o społeczeństwie wiedzy?, „Studia Ekonomiczne” 2014, nr 167, s. 116.

20 P.F. Drucker, Myśli przewodnie Druckera, Warszawa 2002, s. 457.

$21 \quad$ I. Stalończyk, Edukacja..., s. 321.

22 J. Szacki, Wstęp. Powrót idei społeczeństwa obywatelskiego, [w:] J. Szacki (red.), Ani książę, ani kupiec: obywatel, Kraków 1997, s. 5. 
w latach 80. i 90. ubiegłego wieku. Renesans tej idei albo przybierał formę przypomnienia dawniej formułowanych zasad organizacji życia społecznego i pewnych idei, albo wiązał się z krytyką społeczeństwa realnego socjalizmu będąc mu przeciwstawianą wręcz utopistycznie ${ }^{23}$. Jej rozumienie wciąż w znaczny sposób zależy od narodowych tradycji i doświadczeń oraz szerzej - od uwarunkowań cywilizacyjnych.

W klasycznym rozumieniu społeczeństwo obywatelskie jest sumą aktywności obywateli, które nie wynikają z ich ewentualnej roli funkcjonariuszy państwowych, mają postać zorganizowaną, zaś skutkujące tą działalnością relacje społeczne wykraczają poza poziom mikrostruktur społecznych ${ }^{24}$. Jego konstytutywną cechą są wielowymiarowe więzi społeczne między jednostkami zorganizowane w stowarzyszenia i organizacje pozarządowe, a wypadkową określony poziom ${ }^{25}$ kapitału społecznego ${ }^{26}$. Społeczeństwo obywatelskie tworzy więc przestrzeń niewymuszonego ludzkiego stowarzyszenia oraz sieci stosunków nawiązywanych w imię rodziny, wiary, interesu oraz ideologii, ażeby tę przestrzeń wypełnić ${ }^{27}$. Jest więc ono społeczeństwem obywateli świadomych i dążących do bycia świadomymi, kompetentnych obywatelsko, zawodowo, społecznie, kulturowo. Obywateli gotowych do podejmowania decyzji w oparciu o swą wciąż poszerzaną wiedzę. Obywateli uczących się.

Relacja między społeczeństwem obywatelskim, a obywatelami uczącymi się (rzec można - pozostającymi „w procesie lifelong learningu”) ma charakter sprzężony. Obywatelskość społeczeństwa oznacza między innymi jego tendencję do budowania warunków sprzyjających uczeniu się przez całe życie (choćby w ramach pozarządowych organizacji realizujących cele edukacyjne). $\mathrm{Z}$ drugiej strony - ideę społeczeństwa obywatelskiego mogą wypełnić treścią tylko jednostki (obywatele) doceniający wartość edukacji oraz jej całożyciowy wymiar. Dzięki swej wiedzy mogą kompetentnie angażować się w życie

23 A Siciński, Spoleczeństwo obywatelskie a polskie transformacje ustrojowe, [w:] A. Sułek, J. Styk (red.), Ludzie i instytucje. Stawanie się ładu spolecznego, Lublin 1995, s. 144.

24 E. Wnuk-Lipiński, Demokratyczna rekonstrukcja. Z socjologii radykalnej zmiany społecznej, Warszawa 1996, s. 98-100.

25 Do czynników istotnie warunkujących poziom kapitału społecznego należą według A. Cybuli: system polityczny i prawny oraz od sposób sprawowania władzy.

26 A. Cybula, Demokracja w działaniu... a sprawa polska (i ślaska). Esej o stosowalności wloskich badań Roberta D. Putnama w warunkach polskich i ślaskich, [w:] W. Jachera (red.), Eseje socjologiczne, Katowice 2001, s. 177.

27 M. Walzer, Spór o społeczeństwo obywatelskie, [w:] J. Szacki (red.), Ani ksiażę, ani kupiec..., s. 84 . 
społeczne podnosząc jego jakość. Innymi słowy: lifelong learning jest jednocześnie budulcem i miarą kapitału społecznego.

Idea lifelong learningu pozostaje więc immanentnie zespolona $\mathrm{z}$ najważniejszymi kategoriami definiującymi współczesne społeczeństwo i społeczności zwłaszcza, gdy analizowany jest kontekst ich jakościowego wzrostu i rozwoju. Związek ten znajduje swoje odzwierciedlenie na wszystkich poziomach, w sposób szczególny uwidaczniając się na poziomie lokalnym w postaci wyzwań stojących przed samorządami terytorialnymi.

\section{Postulaty i realizacja idei edukacji całożyciowej w świetle dokumentów europejskich}

Odzwierciedleniem rozumienia znaczenia edukacji całożyciowej dla rozwoju społeczeństw jest szereg decyzji podejmowanych na poziomie instytucji europejskich na rzecz jej rozwoju i wspierania. Od momentu przyjęcia Strategii Lizbońskiej Rada Europy zwróciła się do państw członkowskich Unii Europejskiej o opracowanie i wdrożenie spójnych strategii promujących ideę uczenia się przez całe życie. Szczególnego znaczenia nabierają więc fundamentalne zasady przyjęte przez Międzynarodową Komisję ds. Edukacji i Oświaty dla XXI wieku (Komisja UNESCO):

- edukacja jest podstawowym prawem osoby ludzkiej i ma uniwersalną ludzką wartość: nauka i edukacja są celem samym w sobie, do którego powinna dążyć jednostka, jak i społeczeństwo; należy je rozwijać i udostępniać każdemu człowiekowi w ciągu całego życia;

- edukacja - formalna lub nieformalna powinna przynosić pożytek społeczeństwu, dawać mu narzędzia, które sprzyjają twórczości, postępowi, upowszechnianiu wiedzy i nauki, oraz udostępniać wszystkim naukę i oświatę;

- wszelka polityka edukacyjna powinna kierować się troską o sprawiedliwość, racjonalność i doskonałość. Dążenie do harmonijnego zespolenia tych trzech celów jest kardynalnym zadaniem tych wszystkich, którzy biorą udział w planowaniu edukacji i praktycznej działalności edukacyjnej;

- odnowa edukacji i każda wiązana z nią reforma powinny opierać się na przemyśleniach i pogłębionej analizie dostępnych informacji na temat teorii i praktyki, które zostały uwieńczone pozytywnymi rezultatami, jak też na solidnym rozpoznaniu specyficznych warunków i potrzeb. Decyzja 
o podjęciu reform powinna zapadać w wyniku wspólnego porozumienia zainteresowanych stron jako proces średnioterminowy;

- chociaż ogromna różnorodność warunków gospodarczych, społecznych i kulturowych dyktuje oczywiście zróżnicowane podejście do rozwoju edukacji, jednak podejście to powinno uwzględniać fundamentalne wartości i troski, co do których istnieje zgoda w łonie społeczności międzynarodowej i systemu Narodów Zjednoczonych: prawa człowieka, tolerancja i wzajemne zrozumienie, demokracja, odpowiedzialność, uniwersalizm, tożsamość kulturowa, dążenie do pokoju, ochrona środowiska, dzielenie się wiedzą, walka z ubóstwem, regulacja demograficzna, zdrowie;

- odpowiedzialność za edukację spoczywa na całym społeczeństwie, wszystkie zainteresowane osoby i wszyscy partnerzy - oprócz instytucji, do których należy to zadanie - powinni znaleźć swoje miejsce w procesie edukacyjnym ${ }^{28}$.

10 grudnia 1948 r. Zgromadzenie Ogólne Organizacji Narodów Zjednoczonych proklamowało Powszechną Deklarację Praw Człowieka. W artykule 26 Powszechnej Deklaracji Praw Człowieka znalazł się zapis:

- każdy człowiek ma prawo do nauki. Nauka będzie bezpłatna, przynajmniej na szczeblu podstawowym. Nauka podstawowa będzie obowiązkowa. Oświata techniczna i zawodowa będzie powszechnie dostępna, a studia wyższe będą dostępne dla wszystkich na równych zasadach w zależności od uzdolnień;

- nauczanie będzie ukierunkowane na pełen rozwój osobowości ludzkiej i umocnienie poszanowania praw człowieka i podstawowych wolności. Będzie ono krzewić wzajemne zrozumienie, tolerancję i przyjaźń między wszystkimi narodami, grupami rasowymi i religijnymi, a także wspierać działalność Organizacji Narodów Zjednoczonych zmierzającą do utrzymania pokoju;

- $\quad$ rodzice mają prawo pierwszeństwa w wyborze rodzaju nauczania, którym objęte będą ich dzieci²9

W artykule 28 przyjętej przez Zgromadzenie Ogólne ONZ 20 listopada 1989 r. Konwencji o Prawach Dziecka czytamy: „uznaje prawo dziecka do nauki (...) na zasadzie równych szans". Równe szanse dostępu do edukacji, według zapisów zawartych w Konwencji o Prawach Dziecka, dotyczą wszystkich

${ }_{28}$ H. Bednarczyk, T. Gawlik, T. Kupidura (red.), Europejskie idee i inspiracje edukacyjne (wybór dokumentów), Radom 2005, s. 11.

29 Tamże, s. 16-17. 
stopni kształcenia. Strony podpisujące Konwencję zobowiązane są także do popierania i rozwijania międzynarodowej współpracy w dziedzinie oświaty. Zachowane będzie także poszanowanie godności człowieka i jego prawo do pełnego rozwoju, co zawarte jest między innymi w Artykule 29 Konwencji. Prawo do edukacji gwarantują także zapisy art. 165 i 166 Traktatu o funkcjonowaniu Unii Europejskiej (d. art. 149 i 150 Traktatu ustanawiającego Wspólnotę Europejską). Rada Europy w grudniu 2000 roku w Nicei przyjęła Kartę Praw Podstawowych Unii Europejskiej. Artykuł 14 Karty gwarantuje prawo do nauki. Dokumentem zapewniającym takie prawo jest także, w przypadku Polski, Konstytucja Rzeczypospolitej Polskiej ${ }^{30}$ (art. 70) oraz ustawa o systemie oświaty. W preambule ustawy o systemie oświaty ${ }^{31}$ czytamy: „oświata w Rzeczypospolitej Polskiej stanowi wspólne dobro całego społeczeństwa; kieruje się zasadami zawartymi w Konstytucji Rzeczypospolitej Polskiej, a także wskazaniami zawartymi w Powszechnej Deklaracji Praw Człowieka, Międzynarodowym Pakcie Praw Obywatelskich i Politycznych oraz Konwencji o Prawach Dziecka. Nauczanie i wychowanie - respektując chrześcijański system wartości - za podstawę przyjmuje uniwersalne zasady etyki. Kształcenie i wychowanie służy rozwijaniu u młodzieży poczucia odpowiedzialności, miłości ojczyzny oraz poszanowania dla polskiego dziedzictwa kulturowego, przy jednoczesnym otwarciu się na wartości kultur Europy i świata. Szkoła winna zapewnić każdemu uczniowi warunki niezbędne do jego rozwoju, przygotować go do wypełniania obowiązków rodzinnych i obywatelskich w oparciu o zasady solidarności, demokracji, tolerancji, sprawiedliwości i wolności.

Zagadnienie edukacji całożyciowej zostało podjęte w wielu dokumentach, albowiem jest ona rozpatrywana na wielu płaszczyznach. Za przykład posłużyć mogą: Raport Faure'a „Uczyć się, aby być”, Raport Delorsa „Edukacja, jest w niej ukryty skarb”, Biała Księga Komisji Europejskiej „Nauczanie i uczenie się. Na drodze do uczącego się społeczeństwa", Memorandum dotyczące kształcenia ustawicznego.

Jak już zasygnalizowałyśmy, pojęcie edukacji ustawicznej ewaluowało zanim ostatecznie zostało utrwalone. W 1960 roku podczas II Międzynarodowej Konferencji Edukacji Dorosłych w Montrealu dokonano rozszerzenia pojęcia „edukacji dorosłych” od uczenia się dalszego do kształcenia ustawicznego. Oznaczało to przejście od nauki uzupełniającej do tworzenia systemu edukacji

30 Dz.U. Nr 78, poz. 483 ze zm.

31 Ustawa z dnia 7 września 1991 r. o systemie oświaty (tekst jedn. Dz.U. z 2015 r., poz. 2156 ze zm.). 
ustawicznej. W trakcie tej konferencji sformułowano hasło: from continuing education to continuous education (,od kontynuowania kształcenia do kształcenia ciągłego") . Dwanaście lat później, w 1972 r., na konferencji w Tokio, uznano, że edukacja stanowi integralną część kształcenia ustawicznego, które należy rozumieć jako ideę obejmującą cały system edukacji szkolnej i pozaszkolnej, razem z wychowaniem w rodzinie i oświatą dorosłych. Takie ujęcie zostało przyjęte przez UNESCO i w 1974 r. podjęto uchwałę o kształceniu ustawicznym jako dominującej zasadzie reform oświatowych.

Raport „Uczyć się, aby być” (Learning to be, 1972), przygotowany pod kierunkiem Edgara Faure'a, ukazuje rolę edukacji w procesie kształtowania i rozwijania człowieka we wszystkich aspektach na przestrzeni całego życia. Człowiek, zdaniem ekspertów raportu, jest jednostką przeznaczoną do ciągłego wychowywania, zaś taki proces może zachodzić tylko na przestrzeni całego życia. Może to spełnić edukacja permanentna, która, zdaniem Komisji, nie stanowi ani systemu, ani dziedziny czy szczebla kształcenia, lecz jest zasadą, na której oparta powinna być oświata.

Edukacja permanentna jest dla autorów raportu podstawą społeczeństwa wychowującego. Podejmując działania należy pamiętać, aby każdemu zapewnić taką formę wychowania, która odpowiada zdolnościom i oczekiwaniom uczestników tego procesu. Autorzy raportu zwracają uwagę na ogólnoludzkie wartości, jakie wiążą się z edukacją całożyciową: humanizm naukowy, twórczość, zaangażowanie społeczne, odpowiedzialność społeczną, a także realizację ideału pełnego człowieka, charakteryzującego się harmonijnym rozwojem fizycznym, intelektualnym, uczuciowym i etycznym.

Edith Cresson, Parang Flynn i Martin Bangemann - autorzy Białej Księgi Komisji Europejskiej, zatytułowanej „Nauczanie i uczenie się. Na drodze do uczącego się społeczeństwa”, zwrócili uwagę, że „społeczeństwo jutra będzie inwestować w wiedzę i stanie się społeczeństwem uczenia się i nauczania, w którym każdy będzie tworzył swoje kwalifikacje. Innymi słowy powstanie społeczeństwo uczące się". Księga ukazała się w 1995 r. i to na jej kartach zapisano zadania i cele nowej edukacji:

- przywrócenie dobroczynnych skutków szerokich podstaw wiedzy oraz rozwijanie ,przydatności” do zatrudnienia;

- szeroko profilowana wiedza ma być czynnikiem dostosowującym jednostki do sytuacji gospodarczej, a także ma dawać pracownikom łatwość przekwalifikowania się; 
- otwartość na uznawanie wiedzy jednostek oraz stworzenie systemu uznawania różnych składowych kwalifikacji;

- wprowadzenie „osobistej karty kwalifikacyjnej”.

Tak sformułowane cele doprowadziły do opracowania konkretnych propozycji działań, obejmujących: zachęcanie do zdobywania i podnoszenia ogólnego poziomu wiedzy, zbliżanie szkoły i przedsiębiorstwa, walkę z marginalizacją, upowszechnienie znajomości trzech języków Unii Europejskiej, równouprawnienie inwestycji materialnych i nakładów na kształcenie - priorytetowe traktowanie edukacji w sytuacji niewystarczającej konkurencyjności Europy ${ }^{32}$.

Autorzy skoncentrowali się na rozwoju społeczeństwa uczącego się gotowego do zmian, jednak podkreślali, że nie będzie to możliwe dopóki system kształcenia nie będzie pozwalał na przemiany tożsamości indywidualnej i zbiorowej, pozwalając jednocześnie na postęp w dziedzinie technologii i wiedzy. Następstwem publikacji Białej Księgi było wspomniane już ogłoszenie 1996 roku - Rokiem Edukacji Ustawicznej.

W odpowiedzi na rosnące bezrobocie oraz w przekonaniu o możliwości poprawy sytuacji przez edukację, w styczniu 1996 w Paryżu spotkali się ministrowie edukacji krajów członkowskich OECD. Tematem obrad było „Uczynienie edukacji ustawicznej rzeczywistością dla wszystkich”. Dyskutowano nad kształtem edukacji ustawicznej, który odpowiadałby potrzebom globalnej i opartej na informacji ekonomii.

Osiągnięcie ustalonego celu nadrzędnego - „edukacja ustawiczna rzeczywistością dla wszystkich ludzi" - jest możliwe poprzez wdrożenie do edukacji całożyciowej począwszy od wczesnego dzieciństwa aż po kształcenie się na emeryturze. Warunkiem jest stworzenie szans edukacyjnych dla ludzi w każdym wieku, tj. demokratyczne uczestnictwo w kształceniu wszystkich grup społecznych, indywidualny rozwój i samorealizacja obywateli. Uczestnicy paryskiego spotkania wyodrębnili trzy aspekty systemu edukacji i kształcenia zawodowego, postulując:

- umożliwienie wszystkim uczącym się uzyskania akademickich i zawodowych kwalifikacji, które są im niezbędne do pracy i dalszej nauki;

- udoskonalenie (udrożnienie) przejścia pomiędzy edukacją a pracą: szkołą, pracą i szkolnictwem wyższym, a także zwiększenie możliwości kształcenia się dorosłych;

32 A. Matlakiewicz, Edukacja ustawiczna..., s. 21-22. 
- opracowanie na nowo koncepcji wyznaczającej role i odpowiedzialność wszystkich partnerów - włączając w to władze i samych uczących się przy wdrażaniu i finansowaniu kształcenia ustawicznego ${ }^{33}$.

W Roku Edukacji Ustawicznej, został opublikowany Raport „Edukacja, jest w niej ukryty skarb". Raport ten powstał na polecenie Federico Mayora, dyrektora generalnego UNESCO, na potrzeby Międzynarodowej Komisji ds. Edukacji XXI wieku. Pracom przewodniczył Jaques Delors. W pracach udział wzięli przedstawiciele 15 krajów, w tym także z Polski. Zadaniem tego zespołu było opracowanie koncepcji edukacji w XXI wieku. W przygotowaniu Raportu autorom przyświecała idea uczenia się przez całe życie jako podstawa w działaniach podejmowanych przez jednostkę. Według twórców tego Raportu „koncepcja edukacji przez całe życie jawi się jako klucz do bram XXI wieku. Wykracza poza tradycyjny podział na edukację wstępną i edukację ustawiczną. Jest odpowiedzią na wyzwania szybko zmieniającego się świata"34. Postrzegając edukację wszechstronnie i wielowymiarowo Komisja postulowała jej organizację wokół czterech aspektów (które są też filarami wiedzy każdej jednostki):

- nauczyć się, aby wiedzieć;

- uczyć się, aby działać;

- uczyć się, aby żyć wspólnie, uczyć się współżycia z innymi;

- uczyć się, aby byćc 35 .

Dokumentem, który jak klamra spina treści i przesłania tych wcześniej wymienionych jest ogłoszone w $2000 \mathrm{r}$. Memorandum Lifelong Learningu. W jego wstępie zwrócono uwagę, że: ,udanemu przejściu do gospodarki i społeczeństwa opartych na wiedzy musi towarzyszyć zwiększony nacisk na kształcenie ustawiczne (...). Kształcenia ustawicznego nie należy już dłużej postrzegać jako tylko jednego z wielu aspektów edukacji i szkoleń. Powinno ono zyskać miano motywu przewodniego, który zapewni udział w szerokim zakresie różnorakich form kształcenia. Tę wizję należy urzeczywistnić w nadchodzącym dziesięcioleciu. Wszystkim mieszkańcom Europy, bez żadnego wyjątku, należy stwarzać takie same możliwości, by mogli sprostać wymaganiom stawianym

33 Tamże, s. 30.

34 J. Delors (red.), Edukacja - jest w niej ukryty skarb, Raport dla UNESCO Międzynarodowej Komisji ds. Edukacji dla XXI wieku, Wydawnictwo UNESCO, Warszawa 1998, s. $17 \mathrm{i} \mathrm{n.}$

35 A. Matlakiewicz, Edukacja ustawiczna..., s. 25-26. 
przez zmiany społeczne i gospodarcze, a także aktywnie uczestniczyć w budowaniu przyszłości Europy"36.

W dokumencie tym wyróżniono trzy podstawowe kategorie podejmowanego kształcenia: kształcenie formalne, kształcenie nieformalne i kształcenie okazjonalne ${ }^{37}$. Sformułowano również sześć złożeń, ogniskujących cele i działania na rzecz wspierania i rozwoju kształcenia ustawicznego:

- nowe podstawowe umiejętności dla wszystkich;

- zwiększenie inwestycji w zasoby ludzkie;

- innowacyjne metody nauczania i uczenia się;

- uznanie wartości kształcenia;

- zmiana charakteru poradnictwa i doradztwa;

- przybliżenie nauki do miejsca zamieszkania ${ }^{38}$.

Memorandum stało się swoistym drogowskazem do planowanych reform, na drodze do społeczeństwa uczącego się - społeczeństwa opartego na wiedzy.

Zgromadzone doświadczenia i wypracowane strategie doprowadziły do wydania 14 lipca 2004 r. Decyzji Parlamentu Europejskiego i Rady ustanawiającej Zintegrowany Program w zakresie kształcenia ustawicznego, który obejmuje cztery programy sektorowe: Comenius, Erasmus, Leonardo da Vinci, Grundtvig, dodatkowy program „międzysektorowy”, obejmujący rozwój polityki edukacyjnej, uczenie się języków, ITC (information and communication technologies) oraz program Jean Monnet, wspierający działania związane z integracją europejską oraz instytucje i stowarzyszenia prowadzące działalność w dziedzinie edukacji i kształcenia.

Omówione dokumenty dowodzą rozumienia przez przedstawicieli instytucji europejskich znaczenia edukacji całożyciowej jako ciągłego i dynamicznie rozwijającego się procesu. Jest ona właściwie rozpoznawana jako skuteczne narzędzie wspierające rozwój społeczeństw, przeciwdziałający nieprawidłowościom i otwierający nowe możliwości rozwoju, dla kolejnych, wchodzących w ten proces pokoleń. Zjednoczona Europa dąży do tego, aby stać się społeczeństwem opartym na wiedzy i ta idea widoczna jest we wszystkich dokumentach. $Z$ tego też powodu państwa członkowskie zabiegają o wypracowanie jak najlepszych strategii rozwoju, jednocześnie uwzględniając specyfikę

36 Memorandum dotyczace ksztatcenia ustawicznego, Komisja Wspólnot Europejskich, Bruksela 30.10.2000 r., s. 3, http://www.sdsiz.com.pl/userfiles/memorandum_o_kształceniu_ustawicznym_2000r.doc (dostęp: 08.06.2016 r.).

37 Tamże, s. 8.

38 Por.: Memorandum..., ss. 8, 10, 12, 15, 16, 18. 
każdego z narodów. Należy mieć jednak świadomość, że praktyka edukacyjna, choć formalnie kształtowana na poziomie europejskim i państwowym, faktycznie dokonuje się na poziomie lokalnym. Jej organizatorami, a niejednokrotnie i twórcami są zaś jednostki samorządów terytorialnych.

\section{Tworzenie warunków do uczenia się przez całe życie jako zadanie własne gminy}

Zmiana optyki w obszarze celów i zadań edukacji wynikająca z sukcesywnego podnoszenia znaczenia edukacji całożyciowej determinuje zmianę zadań i roli zawodowej edukatorów. Motywowanie ludzi pozostaje co prawda na barkach pedagogów i nauczycieli, ale wzrasta jednocześnie odpowiedzialność samorządów. Aby edukacja całożyciowa mogła być w pełni realizowana winna rozwijać się przede wszystkim w małych społecznościach, a więc niezbędna staje się działalność samorządowców, aby stworzyć jak najlepsze warunki do szeroko rozumianej edukacji. Zasadność oddziaływania w środowisku lokalnym dostrzegali już chociażby: Helena Radlińska, Aleksander Kamiński i Ryszard Wroczyński, którzy podkreślali, że należy przekształcać środowisko w bardziej przyjazne człowiekowi, na miarę potrzeb i dążeń społecznych. Podejmując działania w kierunku kształtowania się społeczeństwa kształcącego się ustawicznie należy pamiętać, że ,społeczeństwo to więź międzyludzka, a zarazem kolebka aspiracji i wizji, które z pewnością są ponadjednostkowe"39.

Także Ewa Przybylska zwraca uwagę na znaczenie inicjatyw obywatelskich, które niosą mieszkańcom nadzieję i szanse na lepsze jutro, na ciekawsze i pełniejsze życie. Koncepcja rozwoju społeczeństwa kształcącego się i budowy silnego państwa demokratycznego, koncentrująca się na ożywieniu „małych ojczyzn".

„Na początku jest wyzwanie, coś, co jest trudne i dotyczy kogoś osobiście, np. podwórko na dużym osiedlu urządzone tak, że mieszkańcy nie wiedzą, co z nim począć (...). tutaj następuje pierwsze przełożenie zwrotnic: Nie kończy się na niezadowoleniu, na skardze albo rezygnacji. Przeciwnie, rozpoczynają się poszukiwania: „Co możemy zrobić?” i „Kto do nas dołączy?” Za tymi poszukiwaniami kryje się pragnienie zmiany w nadziei na poprawę sytuacji oraz życzenie, by znaleźć inne osoby, które mają ten sam problem. Dochodzi

39 Tamże, s. 193 
do spotkania osób zainteresowanych. Tutaj przełożenie zwrotnic następuje po raz drugi: spotkania i rozmowy prowadzą do wspólnego działania"40.

Postrzegane w ten sposób przez pedagogów społeczne wyzwania znajdują swoje bezpośrednie odzwierciedlenie w przepisach regulujących powinności jednostek samorządu terytorialnego (j.s.t.) wobec edukacji, w tym (mniej lub bardziej bezpośrednio) te dotyczące wspierania idei lifelong learningu. $\mathrm{Na}$ mocy ustawy z dnia 8 marca 1990 r. o samorządzie gminnym ${ }^{41}$ zaspakajanie potrzeb edukacyjnych, jako należących do zbiorowych potrzeb wspólnoty, stało się zadaniem własnym gminy ${ }^{42}$. Uzupełnienie procesu przekazywania odpowiedzialności za prowadzenie oświaty władzom lokalnym dokonało się ustawą z dnia 5 czerwca 1998 r. o samorządzie powiatowym ${ }^{43}$, któremu również powierzono pewne zadania oświatowe. W ten sposób praktycznie całość spraw związanych z edukacją, w tym z prowadzeniem oświaty, spoczęła na barkach władz lokalnych, stając się jednym z najbardziej kosztochłonnych zadań realizowanych przez j.s.t. ${ }^{44}$

Art. 7 ustawy o samorządzie gminnym w punkcie 8 wskazuje wprost, że zadania własne gminy obejmują edukację publiczną. Analizując jednak zagadnienie przez pryzmat potrzeby tworzenia warunków do realizacji idei lifelong learning $u$ warto zwrócić uwagę także na wymienioną w punkcie 9 tego samego artykułu kulturę, w tym biblioteki gminne i inne instytucje kultury oraz ochronę zabytków i opiekę nad nimi, które stanowią istotny element przestrzeni właściwej dla edukacji pozaformalnej. W kontekście wykazanych już wcześniej związków między procesami edukacji i budowy społeczeństwa obywatelskiego nie bez znaczenia dla lifelong learningu pozostają też opisane punktami 17. i 18. zadania związane z tworzeniem warunków do działania i rozwoju jednostek pomocniczych i wdrażania programów pobudzania aktywności obywatelskiej oraz promocji gminy ${ }^{45}$.

40 E. Przybylska, Animacja środowisk lokalnych warunkiem rozwoju społeczeństwa wiedzy [w:] E. Przybylska (red.), Andragogiczne watki, poszukiwania, fascynacje. Studia ofiarowane profesor Eugenii Annie Wesołowskiej, Torun 2001, s. 191.

${ }_{41} \quad$ Tekst jedn. Dz.U. z 2016 r., poz. 446.

42 Przy czym chodzi tu o edukację publiczną.

$43 \quad$ Tekst jedn. Dz.U. z 2016 r., poz. 814.

44 J. Filas, Proces budzetowy w oświacie, Warszawa s. 4, https://www.ore.edu.pl/component/phocadownload/category/113-raporty?download=1089:proces-budetowy-w-owiacie (dostęp: 09.06.2016 r.).

45 Dz.U. z 2016 r. poz. 446.

304 
Obowiązki j.s.t. wobec edukacji publiczneje ${ }^{46}$ precyzuje ustawa o systemie oświaty. Zgodnie z jej art. 5. do j.s.t. należy prowadzenie szkół i placówek publicznych. Punkty 5 i 5a konkretyzują kolejno zadania gmin i powiatów w tym zakresie:

,5. Zakładanie i prowadzenie publicznych przedszkoli, w tym z oddziałami integracyjnymi, przedszkoli specjalnych oraz innych form wychowania przedszkolnego, o których mowa w art. 14a ust. 1a, szkół podstawowych oraz gimnazjów, w tym z oddziałami integracyjnymi, z wyjątkiem szkół podstawowych specjalnych i gimnazjów specjalnych, szkół artystycznych oraz szkół przy zakładach karnych, zakładach poprawczych i schroniskach dla nieletnich, należy do zadań własnych gmin.

5a. Zakładanie i prowadzenie publicznych szkół podstawowych specjalnych i gimnazjów specjalnych, szkół ponadgimnazjalnych, w tym z oddziałami integracyjnymi, szkół sportowych i mistrzostwa sportowego oraz placówek wymienionych w art. 2 pkt 3-5 i 7, z wyjątkiem szkół i placówek o znaczeniu regionalnym i ponadregionalnym, należy do zadań własnych powiatu, z zastrzeżeniem ust. 3c."

Jako organy prowadzące dla poszczególnych typów szkół, przedszkoli i placówek oświatowych jednostki samorządu terytorialnego, na mocy ustawy, są więc odpowiedzialne za ich działalność. Odpowiedzialność ta obejmuje obowiązek zapewnienia bezpiecznych i higienicznych warunków do działania placówki (i do prowadzenia w niej nauki, opieki i wychowania), dokonywania remontów i inwestycji, obsługę administracyjną, finansową i organizacyjną szkół i placówek oraz wyposażanie ich w niezbędne pomoce i sprzęt, a także przeprowadzanie sprawdzianów i egzaminów oraz wykonywanie innych zadań statutowych. Poza tak rozumianym prowadzeniem oświaty publicznej ustawodawca zobowiązał j.s.t. do prowadzenia ewidencji szkół i placówek niepublicznych zakładanych przez osoby prawne i fizyczne oraz udzielania im dotacji z własnego budżetu ${ }^{47}$.

Jakkolwiek regulacje prawne dotyczące obowiązków j.s.t. wobec edukacji (a dokładniej wobec konieczności zabezpieczania potrzeb edukacyjnych poszczególnych społeczności) najsilniej akcentują i precyzują zadania związane $\mathrm{z}$ edukacją formalną, to jednak znajdują się w nich odniesienia dotyczące wszystkich innych wymiarów i poziomów edukacji. $Z$ całą pewnością

46 Edukacja publiczna jest tu rozumiana jako jedno $\mathrm{z}$ ważniejszych ogniw w strukturze działań na rzecz tworzenia warunków wspierających ideę lifelong learningu.

47 J. Filas, Proces budżetowy..., s. 4-5. 
wykraczają one dalece poza umożliwianie obywatelom wypełniania obowiązku szkolnego. Kształtując wielorakie elementy społeczno-kulturowego pejzażu środowiska lokalnego j.s.t. tworzą jednocześnie warunki mniej lub bardziej sprzyjające realizacji idei lifelong learningu.

\section{Podsumowanie}

Idea edukacji ustawicznej, idea lifelong learningu zawiera w sobie wciąż nowe wyzwania we wszystkich obszarach życia, zarówno jednostkowego jak i społecznego, i zdecydowanie wychodzi poza obszar tylko i wyłącznie oddziaływań edukacyjnych. Jak napisał Jan Amos Komeński ,całe życie jest szkołą" i to właśnie z tego powodu zadaniem rządów, samorządów, edukatorów jest budowanie przestrzeni sprzyjającej wymianie doświadczeń, budowaniu mostów międzypokoleniowych i docenianie wkładu jednostkowego w rozwój społeczności lokalnej aż po szeroko rozumiane społeczeństwo. Pojęcie społeczeństwa opartego na wiedzy musi zatem stać się hasłem nadrzędnym do kreowania społecznej rzeczywistości, bo tylko takie otwarcie się na Innych pozwoli nam podtrzymać ciągły rozwój, przy zachowaniu należytej troski o indywidualizację grup i ich tożsamości. Edukacja jest tym, co pozwala patrzeć w przód i nie zapominać o tym, co za nami. Takie idee przyświecały twórcom najważniejszych dokumentów międzynarodowych proklamujących idee lifelong learningu i przyświecają nadal. Każdy z krajów wspólnoty posiada Białą Księgę, w której na mapę wytycznych międzynarodowych, nakładane są punkty determinujące odrębność każdego z krajów. To daje szanse na zachowanie status quo oraz gwarantuje, że edukacja nie będzie oderwana od rzeczywistości - pozostanie osadzona w realiach społecznych, gospodarczych i politycznych danego kraju, stanowiąc w praktyce wciąż aktualne wyzwanie dla samorządów terytorialnych.

\section{Literatura}

1. Bednarczyk H., Gawlik T., Kupidura T., Europejskie idee i inspiracje edukacyjne (wybór dokumentów), Instytut Technologii Eksploatacji - Państwowy Instytut Badawczy, Radom 2005.

2. Cybula A., Demokracja $w$ działaniu... a sprawa polska (i ślaska). Esej o stosowalności włoskich badań Roberta D. Putnama w warunkach polskich i ślaskich, [w:] W. Jachera (red.), Eseje socjologiczne, Wydawnictwo Uniwersytetu Śląskiego, Katowice 2001. 
3. Delors J. (red.), Edukacja - jest w niej ukryty skarb, Raport dla UNESCO Międzynarodowej Komisji ds. Edukacji dla XXI wieku, Wydawnictwo UNESCO, Warszawa 1998.

4. Drucker P.F., Myśli przewodnie Druckera, Wydawnictwo MT Biznes, Warszawa 2002.

5. Filas J., Proces budżetowy $w$ oświacie, Wydawnictwo Uniwersytetu Warszawskiego, Warszawa, https://www.ore.edu.pl/component/phocadownload/category/113-raporty?download=1089:proces-budetowy-w-owiacie (dostęp: 09.06.2016).

6. Kędzierski M., Jednostki samorzadu terytorialnego wobec wyzwań edukacyjnych, http://witrynawiejska.org.pl/data/M Kedzierski - Edukacja w samorzadzie.pdf (dostęp: 26.06.2016r.).

7. Kruszewski Z.P., Półturzycki J., Wesołowska E.A., Ksztatcenie ustawiczne. Idee i doświadczenia, NOVUM, Płock 2003.

8. Lipski A, Co wiemy o społeczeństwie wiedzy?, „Studia Ekonomiczne” 2014, nr 167, s. 116-126.

9. Memorandum dotyczace kształcenia ustawicznego, dokument roboczy, Komisja Wspólnot Europejskich, Bruksela 30.10.2000, s. 3, http://www.sdsiz.com.pl/userfiles/memorandum_o_kształceniu_ustawicznym_2000r.doc (dostęp: 08.06.2016 r.).

10. Przybylska E., Animacja środowisk lokalnych warunkiem rozwoju społeczeństwa wiedzy, [w:] E. Przybylska (red.), Andragogiczne watki, poszukiwania, fascynacje. Studia ofiarowane profesor Eugenii Annie Wesołowskiej, Wydawnictwo Uniwersytetu Mikołaja Kopernika, Toruń 2001.

11. Siciński A., Społeczeństwo obywatelskie a polskie transformacje ustrojowe, [w:] A. Sułek, J. Styk (red.), Ludzie i instytucje. Stawanie się ładu społecznego, Lublin 1995.

12. Stalończyk I., Edukacja formalna i pozaformalna w procesie kształtowania społeczeństwa wiedzy, „Nierówności Społeczne a Wzrost Gospodarczy” 2014, nr 1 (37), s. 320-332.

13. Szacki J. (red.), Ani książę, ani kupiec: obywatel, Społeczny Instytut Wydawniczy Znak, Kraków 1997.

14. Trempała E., Edukacja formalna (szkolna) i edukacja nieformalna (równoległa, nieszkolna, pozaszkolna), „Przegląd Pedagogiczny”, 2011, nr 1, s. 95-104.

15. Turos L., Andragogika ogólna, Wydawnictwo Żak, Warszawa 1999.

16. Wnuk-Lipiński E., Demokratyczna rekonstrukcja. Z socjologii radykalnej zmiany spoŁecznej, Warszawa 1996.

17. Wroczyński R., Edukacja ustawiczna, [w:] W. Pomykało (red.), Encyklopedia pedagogiczna, Fundacja „Innowacja”, Warszawa 1997.

18. Wujek T., Kształcenie ustawiczne w świetle Raportu Jaquesa Delorsa, [w:] H. Bednarczyk (red.),Wokót problemów kształcenia ustawicznego, Instytut Technologii Eksploatacji, Warszawa-Ryki-Radom 1999.

Monika Kamper-Kubańska, Karolina Kaszlińska

Państwowa Wyższa Szkoła Zawodowa we Włocławku 